Published in final edited form as:

Future Virol. 2008 May ; 3(3): 225-233. doi:10.2217/17460794.3.3.225.

\title{
Mannose-binding lectin in HIV infection
}

\author{
Sarah Eisen, BA (Hons), MBBS, MRCPCH, \\ Department of Infectious Diseases \& Microbiology, Institute of Child Health, University College \\ London, 30 Guilford Street, London, WC1N 1EH, UK, Tel.: +44 207905 2215; Fax: +44 207813 \\ 8494; s.eisen@ich.ucl.ac.uk
}

Agnieszka Dzwonek, MD, and

Department of Infectious Diseases \& Microbiology, Institute of Child Health, University College London, 30 Guilford Street, London, WC1N 1EH, UK, Tel.: +44 207905 2215; Fax: +44 207813 8494; a.dzwonek@ich.ucl.ac.uk

Nigel J Klein, BSc (Hons), MBBS, MRCP, PhD, FRCPCH ${ }^{\dagger}$

Department of Infectious Diseases \& Microbiology, Institute of Child Health, University College London, 30 Guilford Street, London, WC1N 1EH, UK, Tel.: +44 207905 2215; Fax: +44 207813 8494; n.klein@ich.ucl.ac.uk

\begin{abstract}
Infection with HIV represents a significant global health problem, with high infection rates and high mortality worldwide. Treatment with antiretroviral therapy is inaccessible to many patients and efficacy is limited by development of resistance and side effects. The interactions of HIV with the human immune system, both innate and humoral, are complex and complicated by the profound ability of the virus to disable the host immune response. Mannose-binding lectin, a component of the innate immune system, has been demonstrated to play a role in host-virus interactions. This protein may have a key role in determining host susceptibility to infection, pathogenesis and progression of disease, and may contribute to the extensive variability of host response to infection. Further understanding and manipulation of the mannose-binding lectin response may represent a target for immunomodulation in HIV infection, which may, in conjunction with highly active antiretroviral therapy, allow development of a novel therapeutic approach to HIV infection.
\end{abstract}

\section{Keywords}

CD4; HAART; HIV; innate immunity; mannose-binding lectin

\section{HIV infection: a global health problem}

In 2007, 33.2 million people were living with HIV, with 2.5 million new infections and 2.1 million deaths. The global prevalence of HIV is increasing due to ongoing acquisition of HIV, despite preventative measures, and longer survival time. Mortality is decreasing, largely owing to improved management, particularly with the introduction of highly active antiretroviral therapy (HAART), but only $24 \%$ of sufferers worldwide have access to antiretroviral therapy. The efficacy of treatment, even when available, is limited by the

\footnotetext{
(c) 2008 Future Medicine Ltd

${ }^{\dagger}$ Author for correspondence: Department of Infectious Diseases \& Microbiology, Institute of Child Health, University College London, 30 Guilford Street, London, WC1N 1EH, UK, Tel.: +44 207905 2215; Fax: +44 207813 8494; n.klein@ ich.ucl.ac.uk.
} 
development of viral resistance and drug-related side effects, and prevention and treatment of HIV remains a significant challenge [1].

\section{HIV \& innate immunity}

Early studies of HIV infection focused on the direct infection of host cells, particularly CD4 cells, and their subsequent decline in the circulation. However, it is now clear that the pathophysiology of HIV infection is more complex than simply the direct cytopathic effects of HIV-1 [2], and that other aspects of immunity are also affected. Of particular note is the involvement of components of the innate immune system, including natural killer cells, $\gamma / \delta$ $\mathrm{T}$ cells, interferon-producing cells, the complement system and mannose-binding lectin (MBL).

\section{Mannose-binding lectin}

MBL is an acute phase, multimeric protein of hepatic origin. It belongs to the family of collectins [3] and is integral to the human innate immune response. MBL, in association with MBL-associated serine proteases (Figure 1) [4-6], acts as a pattern recognition molecule, and is able to bind to carbohydrate structures on invading microorganisms, including a variety of Gram-positive and -negative bacteria, yeasts, some viruses and, also, protozoa and other parasites. Binding of its ligands activates the complement system independently of both the classical and alternative complement pathways, promoting killing by activation of the terminal complement pathway. MBL also appears to act as an opsonin [7], and may contribute to the killing of microorganisms independently of its complementmediated effects.

\section{Role of MBL in infection}

MBL contributes significantly to an effective innate immune response to an invading pathogen. Serum MBL levels show considerable variation between individuals. A deficiency in MBL exists in about a third of the population in Caucasians (homozygous and heterozygous for variant alleles), making MBL deficiency the most common immunodeficiency described to date. MBL deficiency is particularly common in African populations, in which it may exceed 50\% [8]. The deficiency is due to point mutations in the $M B L$ gene, located on chromosome 10 [9]. Point mutations within exon 1 (codons 54, 57 and $52-\mathrm{B}, \mathrm{C}$ and $\mathrm{D}$ variants, respectively) result in altered assembly of functional oligomers and consequent variations in serum levels, binding capacity and protein activity (reviewed in [10]). Further polymorphisms in the promoter region also significantly influence expression of MBL (Figure 1), with levels varying during the course of infection by up to threefold.

Deficiency of MBL has been shown to predispose to infection with a variety of microorganisms [12-15], including viruses (reviewed in [16,17]). The impact of MBL deficiency appears to be particularly marked in immunocompromised patients $[18,19]$. Serum MBL level also appears to be related to severity of infection in bacterial sepsis [20]. It is possible that MBL, which plays a key role in response to other infections, is also important in determining the host response to HIV infection. Moreover, as HIV acts by a profound disabling of the host immune response, HIV may be mediating some of its immunosuppressive effects by actions on MBL mediated- pathways.

\section{MBL \& HIV: mechanisms of interaction}

In vitro studies have enabled investigation of the mechanisms by which HIV and MBL may interact in the HIV-infected host. MBL binds various sugars, including $N$-acetyl-D- 
glucosamine, mannose, $N$-acetyl-mannosamine, fucose and glucose. The binding of MBL to a variety of viruses has been shown to be mediated by recognition of glycosylated residues on the viral surface [21]. Expression of viral proteins gp120 and gp41, both containing oligosaccharide side chains of high-mannose type, appears to be crucial for the HIV-MBL interaction [21,22]. gp120 in particular is highly glycosylated, with a high proportion of mannose-containing oligosaccharides. MBL has been shown to interact with a wide range of strains of HIV, including both R5 and X4 [22]. Whilst MBL binding to HIV could be influenced by viral growth conditions, primary isolates of whole virus also appear to bind MBL via mannosylated carbohydrates on the viral surface [22]. Other studies also confirm binding of MBL to high mannose carbohydrates, which is regulated by sialyation [23] and enhanced by alteration of glycosylation [24].

Binding of MBL to HIV envelope glycoproteins may, per se, neutralize the virus [21]. In addition, once bound to HIV virus, MBL may mediate several downstream antiviral effects, including complement activation, increased phagocytic uptake and inhibition of viral entry to susceptible cells. Ezekowitz et al. demonstrated that MBL binds to HIV-infected cell lines and can inhibit HIV infection of lymphoblasts [25]. It has been shown that, once bound to gp120, MBL is able to activate the complement pathway independently of C1q and antibodies [26]. However, the contribution of MBL is unclear, as no correlation has been shown between serum MBL level and complement activation following the addition of HIV to uninfected serum [27]. MBL binding of HIV may also enhance opsonization [28] and viral killing, as has been demonstrated with other microorganisms [7]. Evidence for a neutralization effect is controversial. Ezekowitz et al. demonstrated neutralization of virus by physiological concentrations of MBL using T-cell lines [25]. However, in other studies using primary viral isolates, physiological concentrations of MBL only neutralized the virus by approximately $10 \%[24,28]$. Interestingly, treatment of the virus to increase mannose content also increased the neutralization capacity of MBL. In addition to the mechanisms discussed above, there is also limited data to suggest that MBL may modulate cytokine responses to HIV infection, at least in vitro [29].

MBL may also prevent the uptake of HIV into cells required for its transfer to T cells, such as dendritic cells. A surface lectin expressed by dendritic cells, known as DC-SIGN, mediates the binding of HIV and efficient transfer to T cells [30]. Binding of HIV to this lectin may be competitively blocked by MBL, as shown by Ying et al. [28], by preincubation of HIV with physiological levels of MBL, shown by Ji et al. [31] in virus particles and by Marzi et al. [32] in the simian immunodeficiency virus. MBL has been shown, by Spear et al. [33], to prevent DC-SIGN-mediated transinfection of T cells in vitro, although part of the mechanism appeared to relate to increased phagocytic uptake of HIV by DC-SIGN-bearing cells. It is worth noting that, in addition to the immunoprotective effects of MBL, this interaction may represent a method of viral 'hijacking' of the immune system, with MBL-enhanced phagocytic uptake of HIV allowing the establishment of a viral reservoir within the host immune system.

\section{MBL \& susceptibility to HIV infection}

Epidemiological studies suggest that MBL levels may affect susceptibility to HIV infection between three- and eightfold (Table 1). Several studies have demonstrated an association of genetic variants resulting in low serum MBL levels with increased prevalence of HIV infection [34-36]. Further work by Garred et al. [37] and Prohaszka et al. [38] demonstrated lower serum concentrations of MBL in HIV-seropositive patients compared with negative controls, a finding confirmed by Nielsen et al. [39]. This finding has, however, been contradicted by other studies. Senaldi et al. [40] found MBL levels to be higher in HIV 
patients than controls, and Malik et al. [41] demonstrated that $M B L$ genotype frequencies were similar in Colombian HIV-infected and control individuals.

\section{MBL \& disease progression}

Several studies have examined the relationship between MBL level and progression of HIV infection in human subjects (Table 1). Garred et al. showed in the pre-HAART era that homozygosity for $M B L$ variant alleles is associated with significantly shorter survival time from AIDS diagnosis, although no effect was observed on time to development of AIDS from HIV diagnosis [34]. Vallinoto et al. showed that variant B in exon 1 of the $M B L$ gene was associated with higher viral load [42]. Correlation between MBL levels and severe infection has been demonstrated by Hundt et al., who showed a higher incidence of bacterial pneumonia in those HIV-infected patients with reduced serum MBL [43]. However, many studies demonstrate no correlation between $M B L$ genotype [44], or serum MBL level and clinical course [39.40.44]. Maas et al. showed that variant alleles had a weak effect on time from seroconversion to development of AIDs, and showed a protective effect of these mutations on the development of Kaposi's sarcoma [45].

A subgroup of HIV-infected patients whose disease appears not to progress over time (longterm nonprogressors) may be of particular interest in further unravelling these contradictions. Hundt et al. showed that of six long-term nonprogressors, all were found to have normal MBL levels and proposed that wild-type MBL might be a protective host factor in HIV infection [46].

\section{Pediatric studies}

There is limited data available regarding the interaction of MBL and HIV infection in the pediatric population (Table 2). Boniotto et al. demonstrated that allelic mutations in both exon 1 and the promoter were found more frequently in perinatally exposed, infected Brazilian children than in unexposed and uninfected children, suggesting a possible protective effect of normal serum MBL levels in the context of vertical transmission $[48,49]$. A possible deleterious effect of $M B L$ variants on vertical HIV transmission, which appeared to be reversed by vitamin supplementation, was demonstrated by Kuhn et al. [50]. Amoroso et al. demonstrated that children with rapidly progressing disease are more likely to have variant $M B L$ alleles (variation at codon 54), and that an $M B L$ mutation at this site may confer a relative risk for rapid progression to AIDS [51]. This study, however, failed to demonstrate this relative risk in the context of HIV acquisition, as opposed to progression. In a recent study by our own group [52], the rate of MBL deficiency in HIV-infected children was lower than expected, given the predominantly African ethnicity of the cohort. However, this may in fact be artefactual, due to higher survival rates, in the pre-HAART era, of those patients with the wild-type genotype. In the same study, MBL deficiency was more frequent in those with severe disease, while long-term nonprogressors had a lower rate of $M B L$ variants. This may corroborate the findings of other studies, which indicate that MBL deficiency is deleterious in HIV infection. One study, however, failed to show any association between MBL serum level and disease severity [53].

\section{An apparent paradox?}

Some studies demonstrate an association of high MBL levels with advanced disease (Table 1). Prozhaska et al. found high MBL serum levels to correlate inversely with CD4 count (percentage and absolute number) [38]. It is possible that the presumed protective effect of high MBL on acquisition of infection is lost with progression to AIDS. However, it is also possible that the increased amount of cytokines released in advanced HIV infection, or the consequent opportunistic infections, result in a confounding increase in MBL (which can be 
considered an acute phase protein) in those without low MBL producing variants. This was suggested by Heggelund et al. who found increased MBL levels in patients with advanced disease [47]. However, the increase in MBL was not associated with increases in other acute phase proteins measured. Interestingly, the same study also demonstrated further increases in MBL with the introduction of HAART, accompanied by a good virological response. A similar increase in MBL has also been observed in children with advanced disease [52]. The explanation for this remains unclear.

In summary, studies of the effect of MBL levels on disease progression have yielded confusing and conflicting results. It is likely that interpretation is confounded by changes in MBL levels during the evolution of the HIV infection itself. HIV patients may show misleading increases in MBL levels, which may occur as a consequence of their HIV infection and consequent vulnerability to opportunistic infection.

\section{Conclusion}

There seems little doubt that MBL can bind to the HIV virus. Once bound, its mechanism of action and significance is less clear. Its effects may be mediated by direct inactivation or opsonization, neutralization by activation of complement, cytokine modulation, or inhibition of entry into target immune cells. Evidence for the effect of MBL on disease susceptibility and progression, however, remains confusing. These effects may be determined by factors which remain poorly understood as yet, and may be confounded by the role of MBL as an acute phase protein. It is conceivable that population variability in serum MBL levels, as a result of genetic polymorphism, may contribute to the variability of host response to HIV infection.

\section{Future perspective}

The interaction between MBL and HIV is complex, with implications for susceptibility, progression and ultimately, perhaps, for therapy in HIV infection. It is important that we develop a more detailed understanding of both the protective effect of MBL against HIV in the context of an innate immune response, and the mechanisms by which MBL may be exploited by the virus as part of its pathogenicity. Further understanding of the role of MBL in the host-pathogen interaction may have direct therapeutic implications. It may enable the identification of those patients likely to undergo rapid disease progression, enabling avoidance of unnecessary antiviral therapy and appropriate targeting of HAART, thereby reducing the development of drug-resistant viral strains. Further clarification of the role of MBL in HIV infection may enable targeted use of recombinant MBL, which is currently undergoing trials in other MBL deficiency states.

\section{Executive summary}

\section{HIV infection: a global health problem}

- HIV represents a significant global health problem for which tolerable and effective therapy remains limited.

\section{HIV \& innate immunity}

- The innate, as well as humoral, immune system, is involved in the host-virus interaction.

\section{Mannose-binding lectin}

- Mannose-binding lectin (MBL) is a serum protein of the innate immune system, which acts as a pattern recognition molecule. 
- MBL plays a role in complement activation, opsonization and killing of invading pathogens.

\section{Role of MBL in infection}

- MBL levels vary within the population due to genetic polymorphisms. Deficiency results in increased susceptibility to infection with a variety of organisms, including viruses.

\section{MBL \& HIV: mechanisms of interaction}

- MBL is known to bind to HIV via glycosylated surface residues.

- MBL may interact with HIV by direct inactivation and opsonization, neutralization by complement activation, cytokine modulation, or inhibition of uptake by target cells.

\section{MBL \& susceptibility to HIV infection}

- Data regarding the influence of MBL levels and polymorphisms on susceptibility to HIV infection remains controversial but suggests that low MBL levels may predispose to infection with HIV.

\section{MBL \& disease progression}

- Conflicting data exists regarding the influence of MBL levels on disease progression, but may indicate that MBL deficiency predisposes to a poor outcome.

\section{An apparent paradox?}

- A possible effect of MBL level on disease progression may be confounded by the role of MBL as an acute phase protein.

\section{Pediatric studies}

- Limited data exists for the pediatric population, but may corroborate the findings in adult studies.

\section{Future perspective}

- Further understanding of the role of MBL in HIV infection may allow therapeutic immunomodulation and perhaps even the use of replacement therapy.

\section{Acknowledgments}

Financial \& competing interests disclosure

NK provides medical advice to a company which is producing recombinant MBL. The authors have no other relevant affiliations or financial involvement with any organization or entity with a financial interest in or financial conflict with the subject matter or materials discussed in the manuscript apart from those disclosed.

No writing assistance was utilized in the production of this manuscript.

\section{Bibliography}

Papers of special note have been highlighted as either of interest $(\bullet)$ or of considerable interest $(\bullet)$ to readers.

1. Tozser J. HIV inhibitors: problems and reality. Ann. N. Y. Acad. Sci. 2001; 946:145-159. [PubMed: 11762983] 
2. Grossman Z, Meier-Schellersheim M, Sousa AE, Victorino RM, Paul WE. CD4 ${ }^{+}$T-cell depletion in HIV infection: are we closer to understanding the cause? Nat. Med. 2002; 8:319-323. [PubMed: 11927927]

3. Holmskov U, Malhotra R, Sim RB, Jensenius JC. Collectins: collagenous C-type lectins of the innate immune defense system. Immunol. Today. 1994; 15:67-74. [PubMed: 8155265]

4. Matsushita M, Fujita T. Activation of the classical complement pathway by mannose-binding protein in association with a novel C1s-like serine protease. J. Exp. Med. 1992; 176:1497-1502. [PubMed: 1460414]

5. Thiel S, Vorup-Jensen T, Stover CM, et al. A second serine protease associated with mannanbinding lectin that activates complement. Nature. 1997; 386:506-510. [PubMed: 9087411]

6. Dahl MR, Thiel S, Matsushita M, et al. MASP-3 and its association with distinct complexes of the mannan-binding lectin complement activation pathway. Immunity. 2001; 15:127-135. [PubMed: 11485744]

7. Neth O, Jack DL, Johnson M, Klein NJ, Turner MW. Enhancement of complement activation and opsonophagocytosis by complexes of mannose-binding lectin with mannose-binding lectinassociated serine protease after binding to Staphylococcus aureus. J. Immunol. 2002; 169:4430 4436. [PubMed: 12370377]

8. Madsen HO, Satz ML, Hogh B, Svejgaard A, Garred P. Different molecular events result in low protein levels of mannan-binding lectin in populations from southeast Africa and South America. J. Immunol. 1998; 161:3169-3175. [PubMed: 9743385]

9. Hansen S, Holmskov U. Structural aspects of collectins and receptors for collectins. Immunobiology. 1998; 199:165-189. [PubMed: 9777404]

10. Turner MW. Mannose-binding lectin: the pluripotent molecule of the innate immune system. Immunol. Today. 1996; 17:532-540. [PubMed: 8961631]

11. Madsen HO, Garred P, Thiel S, et al. Interplay between promoter and structural gene variants control basal serum level of mannan-binding protein. J. Immunol. 1995; 155:3013-3020. [PubMed: 7673719]

12. Koch A, Melbye M, Sorensen P, et al. Acute respiratory tract infections and mannose-binding lectin insufficiency during early childhood. JAMA. 2001; 285:1316-1321. [PubMed: 11255386]

13. Garred P, Madsen HO, Svejgaard A, Michaelsen TE. Mannose-binding lectin and meningococcal disease. Lancet. 1999; 354:336. [PubMed: 10440334]

14. Hibberd ML, Sumiya M, Summerfield JA, Booy R, Levin M, Meningococcal Research Group. Association of variants of the gene for mannose-binding lectin with susceptibility to meningococcal disease. Lancet. 1999; 353:1049-1053. [PubMed: 10199352]

15. Summerfield JA, Sumiya M, Levin M, Turner MW. Association of mutations in mannose binding protein gene with childhood infection in consecutive hospital series. BMJ. 1997; 314:1229-1232. [PubMed: 9154025]

16. Eisen DP, Minchinton RM. Impact of mannose-binding lectin on susceptibility to infectious diseases. Clin. Infect. Dis. 2003; 37:1496-1505. [PubMed: 14614673]

17. Dommett RM, Klein N, Turner MW. Mannose-binding lectin in innate immunity: past, present and future. Tissue Antigens. 2006; 68:193-209. [PubMed: 16948640] •• Recent review explaining the various scientific and clinical properties of mannose-binding lectin (MBL).

18. Neth O, Hann I, Turner MW, Klein NJ. Deficiency of mannose-binding lectin and burden of infection in children with malignancy: a prospective study. Lancet. 2001; 358:614-618. [PubMed: 11530147]

19. Neth OW, Bajaj-Elliott M, Turner MW, Klein NJ. Susceptibility to infection in patients with neutropenia: the role of the innate immune system. Br. J. Haematol. 2005; 129:713-722. [PubMed: 15952996] - Important paper showing that MBL deficiency predisposes to infection in the context of a co-existing immunodeficiency. This is pertinent to the concept of MBL operating in the context of HIV infection.

20. Fidler KJ, Wilson P, Davies JC, et al. Increased incidence and severity of the systemic inflammatory response syndrome in patients deficient in mannose-binding lectin. Intensive Care Med. 2004; 30:1438-1445. [PubMed: 15127191] 
21. Thielens NM, Tacnet-Delorme P, Arlaud GJ. Interaction of C1q and mannan-binding lectin with viruses. Immunobiology. 2002; 205:563-574. [PubMed: 12396016]

22. Saifuddin M, Hart ML, Gewurz H, Zhang Y, Spear GT. Interaction of mannose-binding lectin with primary isolates of human immunodeficiency virus type 1. J. Gen. Virol. 2000; 81:949-955. [PubMed: 10725420]

23. Hart ML, Saifuddin M, Uemura K, et al. AIDS Res. Hum. Retroviruses. 2002; 18:1311-1317. [PubMed: 12487819]

24. Hart ML, Saifuddin M, Spear GT. High mannose glycans and sialic acid on gp120 regulate binding of mannose-binding lectin (MBL) to HIV type 1. J. Gen. Virol. 2003; 84:353-360. [PubMed: 12560567]

25. Ezekowitz RA, Kuhlman M, Groopman JE, Byrn RA. A human serum mannose-binding protein inhibits in vitro infection by the human immunodeficiency virus. J. Exp. Med. 1989; 169:185-196. [PubMed: 2909656] • First paper to demonstrate that MBL could limit HIV infectivity of lymphoblasts in vitro.

26. Haurum JS, Thiel S, Jones IM, et al. Complement activation upon binding of mannan-binding protein to HIV envelope glycoproteins. AIDS. 1993; 7:1307-1313. [PubMed: 8267903]

27. Saarloos MN, Lint TF, Spear GT. Efficacy of HIV-specific and 'antibody-independent' mechanisms for complement activation by HIV-infected cells. Clin. Exp. Immunol. 1995; 99:189195. [PubMed: 7851010]

28. Ying H, Ji X, Hart ML, et al. Interaction of mannose-binding lectin with HIV type 1 is sufficient for virus opsonization but not neutralization. AIDS Res. Hum. Retroviruses. 2004; 20:327-335. [PubMed: 15117456]

29. Heggelund L, Mollnes TE, Espevik T, et al. Modulatory effect of mannose-binding lectin on cytokine responses: possible roles in HIV infection. Eur. J. Clin. Invest. 2005; 35:765-770. [PubMed: 16313253]

30. Geijtenbeek TB, van Kooyk Y. DC-SIGN: a novel HIV receptor on DCs that mediates HIV-1 transmission. Curr. Top. Microbiol. Immunol. 2003; 276:31-54. [PubMed: 12797442]

31. Ji X, Olinger GG, Aris S, et al. Mannose-binding lectin binds to Ebola and Marburg envelope glycoproteins, resulting in blocking of virus interaction with DC-SIGN and complement-mediated virus neutralization. J. Gen. Virol. 2005; 86:2535-2542. [PubMed: 16099912]

32. Marzi A, Mitchell DA, Chaipan C, et al. Modulation of HIV and SIV neutralization sensitivity by DC-SIGN and mannose-binding lectin. Virology. 2007; 368:322-330. [PubMed: 17659761]

33. Spear GT, Zariffard MR, Xin J, Saifuddin M. Inhibition of DC-SIGN-mediated trans infection of T cells by mannose-binding lectin. Immunology. 2003; 110:80-85. [PubMed: 12941144] • This paper makes an important contribution to understanding of the mechanism of influence of MBL on the infection of CD4 cells in HIV infection.

34. Garred P, Madsen HO, Balslev U, et al. Susceptibility to HIV infection and progression of AIDS in relation to variant alleles of mannose-binding lectin. Lancet. 1997; 349:236-240. [PubMed: 9014910] • Demonstrated the association between MBL deficiency and susceptibility to (and modulation of severity of) HIV infection.

35. Pastinen T, Liitsola K, Niini P, Salminen M, Syvanen AC. Contribution of the CCR5 and MBL genes to susceptibility to HIV type 1 infection in the Finnish population. AIDS Res. Hum. Retroviruses. 1998; 14:695-698. [PubMed: 9618082]

36. Garcia-Laorden MI, Pena MJ, Caminero JA, et al. Influence of mannose-binding lectin on HIV infection and tuberculosis in a Western-European population. Mol. Immunol. 2006; 43:21432150. [PubMed: 16500704]

37. Garred P, Richter C, Andersen AB, et al. Mannan-binding lectin in the sub-Saharan HIV and tuberculosis epidemics. Scand. J. Immunol. 1997; 46:204-208. [PubMed: 9584002] •• Demonstrated the association between MBL deficiency and susceptibility to (and modulation of severity of) HIV infection.

38. Prohaszka Z, Thiel S, Ujhelyi E, et al. Mannan-binding lectin serum concentrations in HIVinfected patients are influenced by the stage of disease. Immunol. Lett. 1997; 58:171-175. [PubMed: 9293399] 
39. Nielsen SL, Andersen PL, Koch C, Jensenius JC, Thiel S. The level of the serum opsonin, mannanbinding protein in HIV-1 antibody-positive patients. Clin. Exp. Immunol. 1995; 100:219-222. [PubMed: 7743658]

40. Senaldi G, Davies ET, Mahalingam M, et al. Circulating levels of mannose binding protein in human immunodeficiency virus infection. J. Infect. 1995; 31:145-148. [PubMed: 8666845]

41. Malik S, Arias M, Di Flumeri C, Garcia LF, Schurr E. Absence of association between mannosebinding lectin gene polymorphisms and HIV-1 infection in a Colombian population. Immunogenetics. 2003; 55:49-52. [PubMed: 12715245]

42. Vallinoto AC, Menezes-Costa MR, Alves AE, et al. Mannose-binding lectin gene polymorphism and its impact on human immunodeficiency virus 1 infection. Mol. Immunol. 2006; 43:13581362. [PubMed: 16214215]

43. Hundt M, Heiken H, Schmidt RE. Association of low mannose-binding lectin serum concentrations and bacterial pneumonia in HIV infection. AIDS. 2000; 14:1853-1854. [PubMed: 10985324]

44. McBride MO, Fischer PB, Sumiya M, et al. Mannose-binding protein in HIV-seropositive patients does not contribute to disease progression or bacterial infections. Int. J. STD AIDS. 1998; 9:683688. [PubMed: 9863582]

45. Maas J, de Roda Husman AM, Brouwer M, et al. Presence of the variant mannose-binding lectin alleles associated with slower progression to AIDS. Amsterdam Cohort Study. AIDS. 1998; 12:2275-2280. [PubMed: 9863869]

46. Hundt M, Heiken H, Schmidt RE. Low mannose-binding lectin serum concentrations in HIV longterm nonprogressors? AIDS Res. Hum. Retroviruses. 2000; 16:1927. [PubMed: 11118079]

47. Heggelund L, Mollnes TE, Ueland T, et al. Mannose-binding lectin in HIV infection: relation to disease progression and highly active antiretroviral therapy. J. Acquir. Immune. Defic. Syndr. 2003; 32:354-361. [PubMed: 12640191]

48. Boniotto M, Crovella S, Pirulli D, et al. Polymorphisms in the $M B L 2$ promoter correlated with risk of HIV-1 vertical transmission and AIDS progression. Genes Immun. 2000; 1:346-348. [PubMed: 11196698]

49. Boniotto M, Braida L, Pirulli D, et al. MBL2 polymorphisms are involved in HIV-1 infection in Brazilian perinatally infected children. AIDS. 2003; 17:779-780. [PubMed: 12646810]

50. Kuhn L, Coutsoudis A, Trabattoni D, et al. Synergy between mannose-binding lectin gene polymorphisms and supplementation with vitamin A influences susceptibility to HIV infection in infants born to HIV-positive mothers. Am. J. Clin. Nutr. 2006; 84:610-615. [PubMed: 16960176]

51. Amoroso A, Berrino M, Boniotto M, et al. Polymorphism at codon 54 of mannose-binding protein gene influences AIDS progression but not HIV infection in exposed children. AIDS. 1999; 13:863-864. [PubMed: 10357389] • Demonstrated the association of variant $M B L$ alleles with increased susceptibility to, and rapid disease progression in, HIV infection.

52. Dzwonek A, Novelli V, Bajaj-Elliott M, et al. Mannose-binding lectin in susceptibility and progression of HIV-1 infection in children. Antivir. Ther. 2006; 11:499-505. [PubMed: 16856624]

53. Lian YC, Della-Negra M, Rutz R, et al. Immunological analysis in paediatric HIV patients at different stages of the disease Scand. J. Immunol. 2004; 60:615-624. 


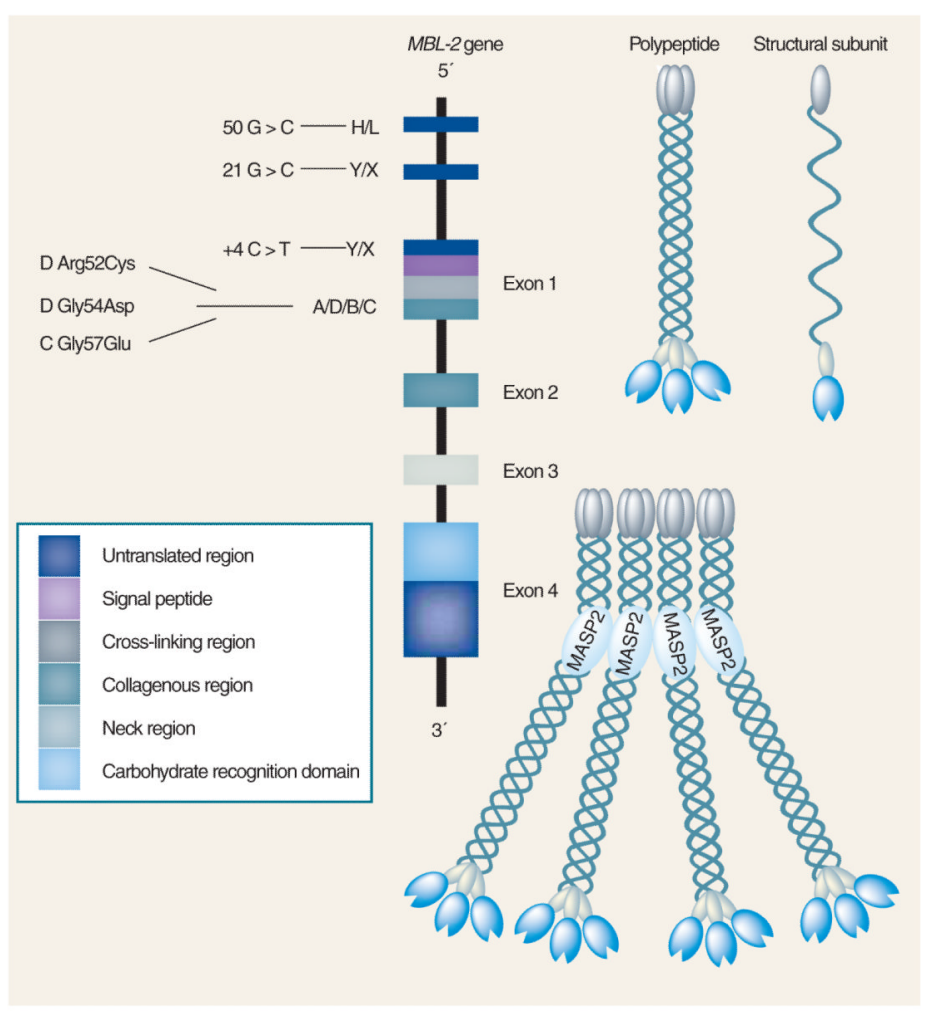

Figure 1. The human $M B L-2$ gene and the encoded protein product

Positions of the exon 1 and promoter polymorphisms are shown. Three identical 32-kDa polypeptides form a structural subunit based on the formation of a collagenous triple helix. Oligomerization of the structural subunit results in mannose-binding lectin molecules of different size, but the tetrameric form shown is thought to be the most common.

Reproduced with permission from [17]. 


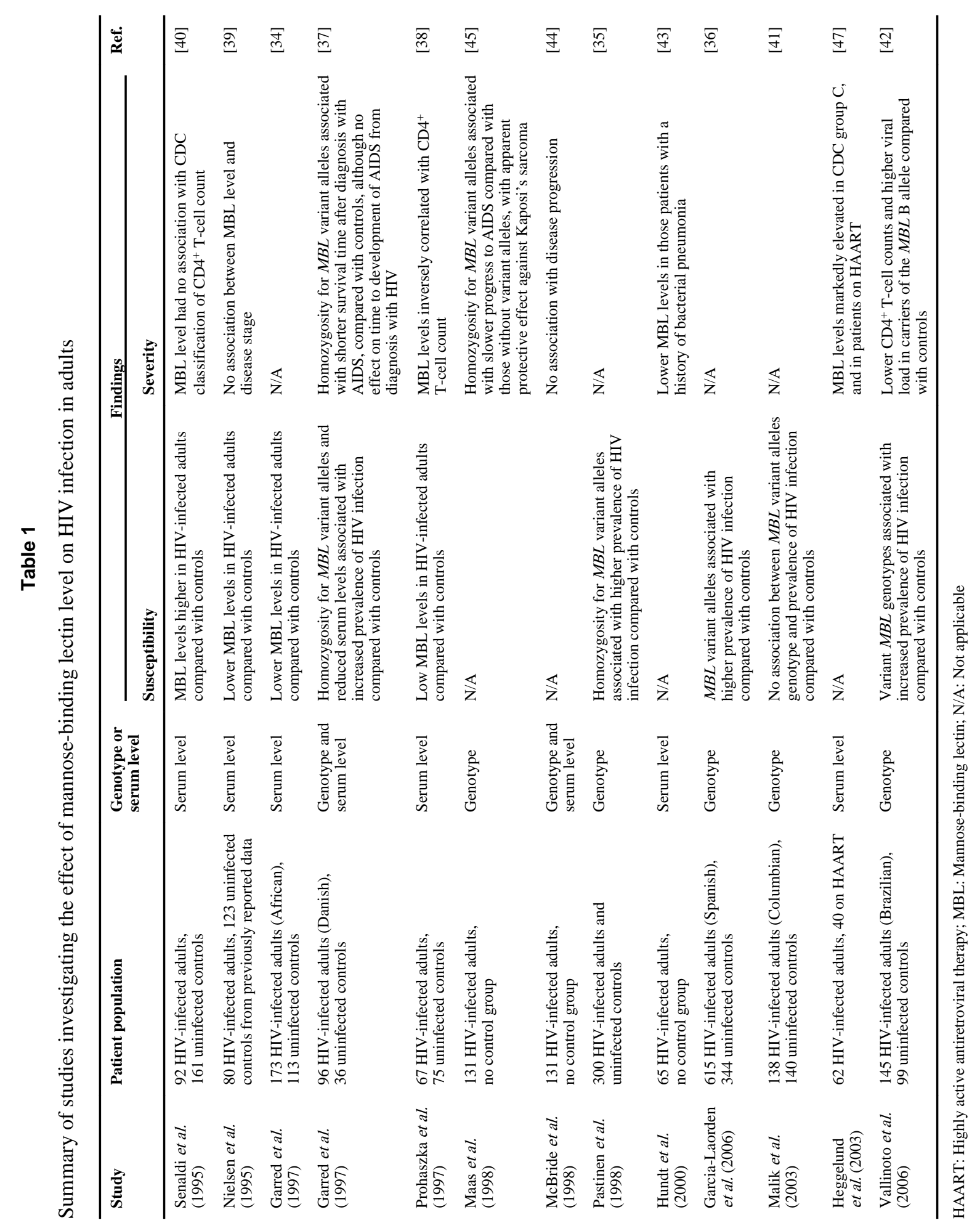

Future Virol. Author manuscript; available in PMC 2011 January 07. 


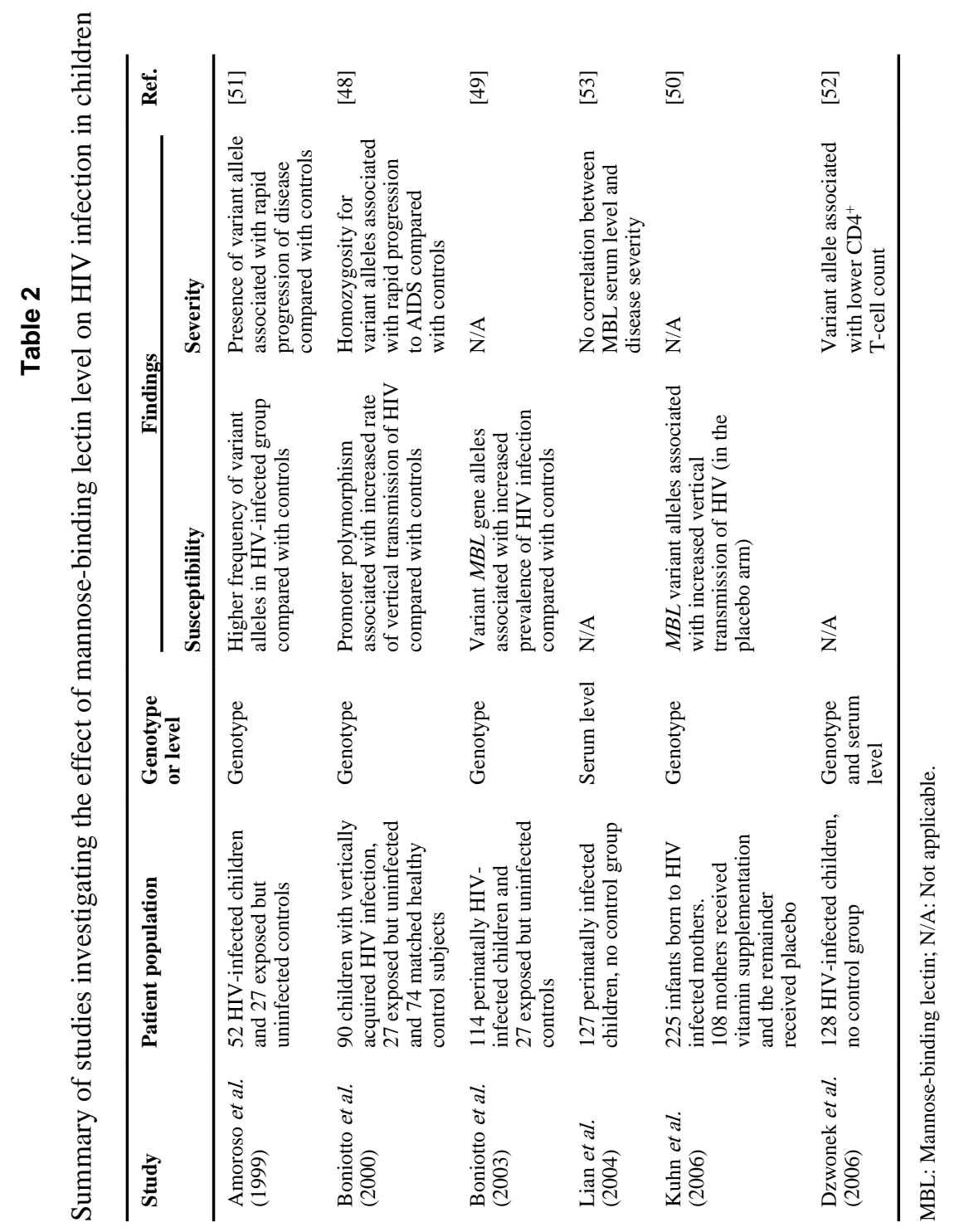

Future Virol. Author manuscript; available in PMC 2011 January 07. 